\title{
A khóra e alhures: uma observação sobre a eskhatiá na Electra de Eurípides
}

\author{
Márcia Cristina Lacerda Ribeiro*
}

RIBEIRO, M.C.L. A khóra e alhures: uma observação sobre a eskhatiá na Electra de Eurípides. R. Museu Arq. Etn., 31: 96-109, 2018

Resumo: Eurípides (485 a.C.- 406 a.C.) levou aos palcos do teatro de Atenas uma releitura sui generis do mito de Electra por volta de 415 a.C. O poeta transpôs com engenhosidade toda a trama para o espaço rural e acrescentou um personagem fundamental no desenrolar da peça, o ancião, preceptor de Agamenão. Expulso da ásty pelo tirano Egisto, o ancião habita o limite fronteiriço da cidade e exerce atividade agropastoril em sua propriedade. Nosso objetivo é examinar a fazendola do fiel servo da família Atrida, localizada em uma eskhatiá. Diferentemente de alguns estudos modernos que veem essas terras limítrofes como improdutivas ou destinadas exclusivamente às atividades marginais, a exemplo da caça e da extração da lenha, ou um apêndice quase isolado da pólis, perfilamos com pesquisas que veem a eskhatiá como espaço integrante da pólis, espaço complexo, plural, muitas vezes absolutamente produtivo.

Palavras-chave: Tragédia euripidiana; Electra; Khóra; Eskhatiá.

No próprio momento em que, pelo jogo cênico e pela máscara, a personagem trágica toma as dimensões de um desses seres excepcionais que a cidade cultua, a lingua a aproxima dos homens. Essa aproximação a torna, em sua aventura lendária, como que contemporânea do público. Consequentemente no íntimo de cada protagonista, encontrase a tensão que notamos entre o passado e o presente, o universo do mito e o da cidade. A mesma personagem trágica aparece ora projetada num longínquo passado mítico, herói de uma outra época, carregado de um poder religioso terrivel, encarnando todo o descomedimento dos antigos reis da lenda - ora falando, pensando, vivendo a própria época da cidade, como um "burguês" de Atenas no meio de seus concidadãos. Jean-Pierre Vernant, Mito e tragédia na Grécia antiga

Furípides (485 a.C.406 a.C.) levou aos palcos do teatro de Atenas uma releitura sui generis do mito dos irmãos Orestes e Electra por volta de 415 a.C. Diferentemente dos seus antecessores que retrataram o mesmo mito no espaço da ásty ${ }^{1}$ - Ésquilo (Coéforas, 458 a.C.) e Sófocles (Electra, cerca de 415 a.C.) -, Eurípides

1 Ásty: espaço urbano da pólis. Os termos gregos são grafados seguindo o glossário do Laboratório de Estudos sobre a Cidade Antiga - Labeca (2013). transpôs com engenhosidade toda a trama para o espaço rural e a um personagem, que sequer aparece na obra de Ésquilo, ele atribuiu um papel ímpar, de protagonista, no desenrolar da trama. Trata-se do ancião, antigo preceptor de Agamenão. Expulso da pólis pelo tirano ${ }^{2}$ Egisto,

2 Tomamos de empréstimo de Newton Bignotto (1998: 52) o uso do termo tirano, que o autor emprega diretamente ao Egisto de Ésquilo em Coéforas, muito embora, como acentua, o Egisto de Eurípides terá importância maior ainda. O covarde tirano euripidiano 
o ancião habita o limite fronteiriço da cidade e exerce atividade agropastoril em sua propriedade. É para este personagem e sua fazendola, localizada em uma eskhatiá, que desviaremos nosso olhar. Diferentemente de alguns estudos modernos que veem essas terras limítrofes como improdutivas ou destinadas exclusivamente às atividades marginais, a exemplo da caça e da extração da lenha, ou ainda como um apêndice quase isolado da pólis, perfilamos com estudiosos que veem a eskhatiá como espaço integrante da pólis, espaço complexo, plural, muitas vezes absolutamente produtivo.

Nosso objetivo é, portanto, analisar a Electra a partir do cenário rural apresentado por Eurípides no intuito de observar com mais acuidade o espaço da eskhatiá. O poeta não tinha preocupação em traçar para o seu espectador um retrato pormenorizado do espaço, alguns detalhes seriam suficientes para o pronto entendimento da tragédia, cuja matéria é pertença de todos o mito. Contudo, Eurípides nos permite entrever uma hinterlândia pulsante, plural, onde é

assassina o rei, usurpa o trono e os bens palaciais e governa os súditos com violência, exilando e matando os inimigos, protegido por uma guarda nos muros da cidade. possivel conhecermos desde as muralhas até as diferentes propriedades rurais e sua economia.

\section{A pólis e sua ordenação espacial}

Antes de nos dirigirmos à pólis euripidiana, recordemos alguns aspectos da organização do espaço da cidade grega. Enquanto realidade física, a pólis abrangia um conjunto de espaços assim distribuídos: (1) a ásty - centro urbano propriamente dito, onde se encontravam a ágora, os prédios públicos, a acrópole, a área residencial, os subúrbios e portos (em algumas cidades), além de templos; (2) muralhas - muitas pólis contavam com um circuito de muros, repleto de portas e torres de vigilância que faziam a divisa da área urbana com a sua hinterlândia; (3) a hinterlândia, território ou khóra - era o espaço rural além-muros que abrigava desde campos de cultivo, necrópoles, fruirion (fortes para proteger o território), templos, pedreiras e minas, além de habitações e diferentes propriedades rurais; (4) as eskhatiai (singular: eskhatiâ) - compreendiam as terras limítrofes, fronteiras com outras pólis e que, às vezes, desembocavam em um rio (Kormikiari et al. 2011).

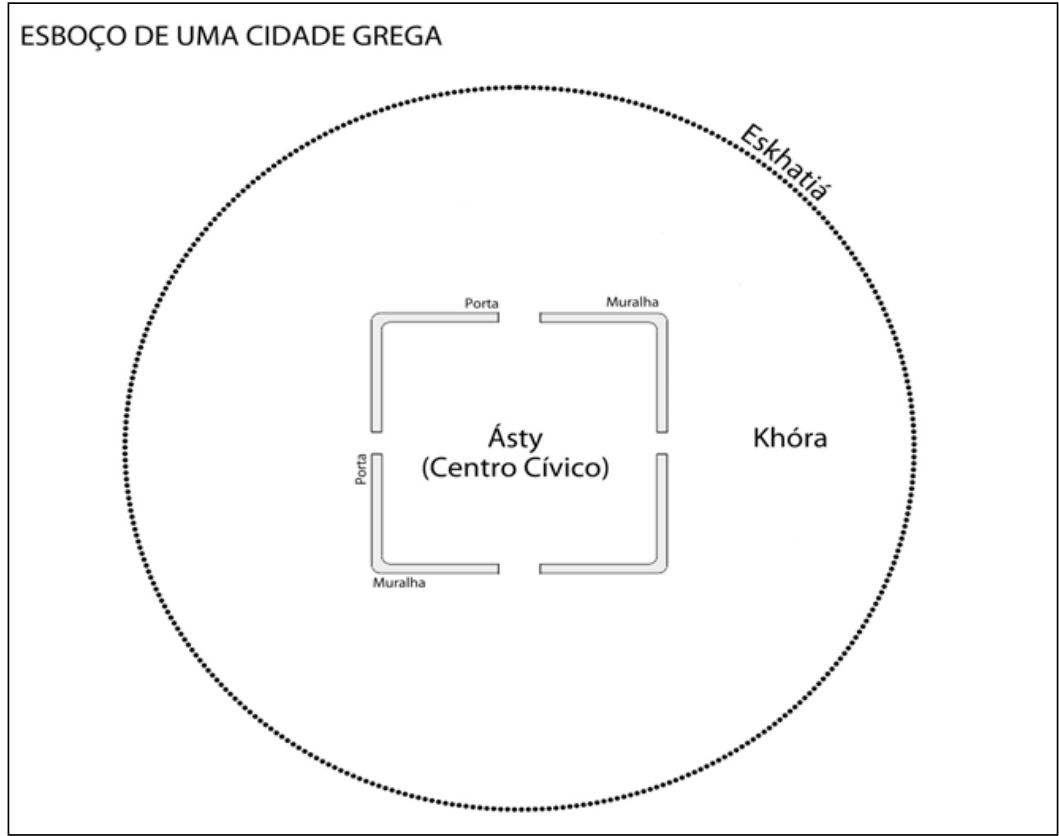

Fig. 1. Esboço de uma cidade grega.

Fonte: Ribeiro (2015: 163) - elaborado por Rodrigo Araújo de Lima. 
Podemos observar no resumido esboço (Fig. 1) a abrangência da khóra - espaço de atuação de todos os personagens da Electra. Em síntese, a khóra pode ser assim definida:

[Um] território apenso aos núcleos urbanos das várias pólis gregas; a hinterlândia "rural" controlada por uma pólis ou, ao menos, sujeita à expectativa de controle por uma pólis. Entendemos que a khóra em uma pólis era parte estruturante da sociedade e que depende do conhecimento das formas de sua ocupação e uso e da sua interação com a ásty a nossa compreensão da natureza mesma da cidade antiga. (Florenzano 2014: 3)

Em que pese a existência dos circuitos de muros em torno da ásty, presentes em muitas pólis, Maria Beatriz Borba Florenzano (2014: 7-10) observa que o grego não sentia a necessidade de linhas estritas demarcando o território. A fronteira seria, portanto, fluida, flexível:

\section{As cidades gregas abriam-se ao território e} o tornavam acessivel ao dominio, ao poder, sem necessariamente marcar uma fronteira linear, de controle territorial contínuo. E sem sujeitar necessariamente a periferia ao centro em uma relação de dependência. (Florenzano 2014: 7)

As pesquisas que vêm sendo empreendidas pelo Labeca têm nos permitido compreender o espaço rural em sua complexidade e singularidade ${ }^{3}$. Não podemos pensar em um mundo rural uniforme e estático no tempo e no espaço nem para uma mesma cidade nem para o conjunto das cidades gregas. De igual modo, não podemos admitir o propalado modelo dicotômico da organização física da cidade, opondo o centro urbano ao território, cujas muralhas representariam o elemento de segregação dessas duas grandes áreas.

As muralhas possuíam inúmeras portas, o que permitia à cidade assumir feições tanto de uma cidade aberta quanto de uma cidade fechada.

3 Vale a pena uma visita ao site do Laboratório, onde há a produção dos seus integrantes, seus projetos e relatórios de pesquisa (http://labeca.mae.usp.br).
Nesse sentido, Aristóteles (1960) acreditava ser mais vantajoso uma cidade amuralhada, posto que ela pudesse assumir as duas faces - cidade aberta ou cidade fechada - conforme suas conveniências. As portas davam acesso a vias que ligavam várias partes do centro urbano a outras tantas no espaço rural, às vezes até a outras cidades (Florenzano 2014: 7). A hinterlândia se abria ao mundo estrangeiro, ao contato com o grego e com o não grego; era por vezes um grande espaço de passagem com diversas rotas interioranas e trilhas percorridas tanto a pé quanto em carro de tração animal (Tacla et al. 2011: 157).

Parece-nos perfeitamente possivel constatar muitos dos pressupostos anteriormente mencionados sobre o espaço dos muros e além-muros na Electra de Eurípides. O poeta se detém com minúcias ao apresentar a khóra, evidenciando a profunda riqueza de um espaço dinâmico, complexo e vivo: um universo absolutamente contraditório e complexo. Argos - nosso cenário - é apresentada como uma cidade circundada por muralhas fortemente vigiadas, mas que permite o vai e vem de pessoas e a circulação de ideias/notícias. A khóra é aberta ao mundo exterior, visto que é uma rota de passagem tomada por Orestes para o Alfeu, quando se apresenta a Egisto passandose por um atleta (Eurípides, Electra: v. 780-785)4. Trata-se de uma khóra heterogênea, com suas necrópoles (a de Agamenão), seus santuários (o de Hera) e suas propriedades em níveis diversos de abastança, que variam desde o pobre casebre de Electra e a humilde propriedade rural do seu esposo, passando pela fazendola bem guarnecida do ancião, na eskhatiá, à fazenda suntuosa de Egisto.

\section{A hinterlândia da Electra de Eurípides}

Os antecedentes do mito dos irmãos Atridas, Electra e Orestes dão-nos conta de que Agamenão, ao retornar vencedor da guerra de Troia, foi assassinado por Clitemnestra, sua

4 A partir de agora indicaremos apenas os versos entre parênteses para menções à Electra de Eurípides. 
esposa, e por Egisto, com quem ela se aliou em conúbio. Orestes, único filho varão de Agamenão, potencial vingador dos assassinos do pai, foi então enviado à Fócida para escapar da ira do tirano, usurpador do trono de Argos. Homem feito, o príncipe retornou secretamente à pátria argiva no intuito de fazer justiça aos homicidas, reaver o trono e reverenciar a terra natal. Pelo mapa apresentado na Fig. 2 é possível acompanhar a mobilidade e a localização dos personagens no drama.

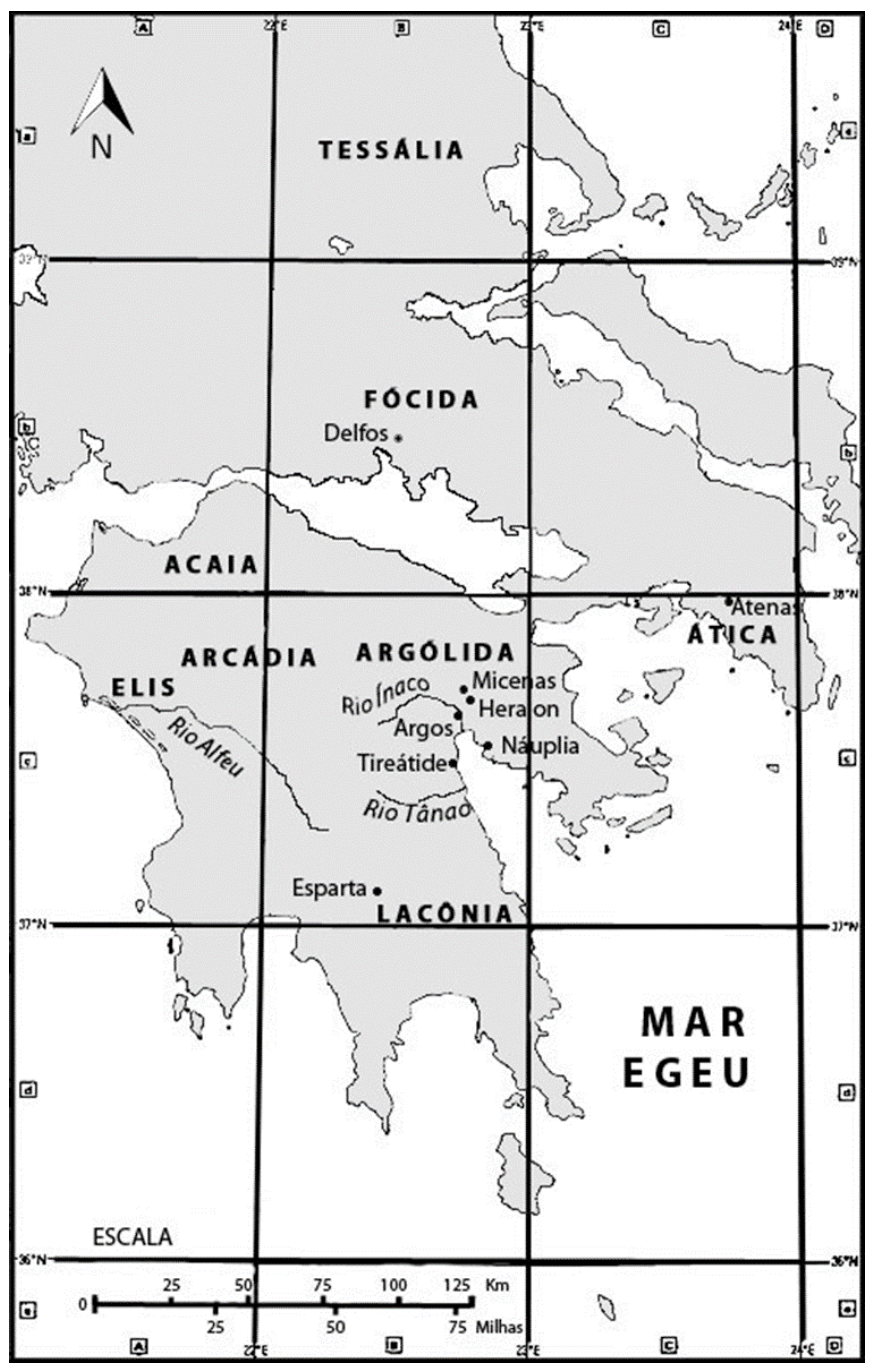

Fig. 2. O mapa de Eurípides e Electra.

Fonte: Ribeiro 2015 - adaptado por Rodrigo Araújo Lima a partir de Lewis (2008).

Até essa altura, Ésquilo, Sófocles e Eurípides convergem no entendimento do mito. A partir de então, vemos Eurípides tomar uma distância ciclópica na reescritura do drama, particularmente no que respeita a questão do espaço. Enquanto Ésquilo e Sófocles optam por um cenário unicamente urbano - embora o primeiro dê especial ênfase ao túmulo de Agamenão, localizado na ásty, e o segundo priorize o espaço do palácio como centro da encenação -, Eurípides, pelo contrário, transpõe toda a ação para a área rural, 
especificamente para frente da casa de Electra. Traz o túmulo de Agamenão para o espaço além-muros, bem como todos os personagens.

O espaço cênico representado na skene da Electra, aquele que é visto pelo espectador, é a fachada da casa da princesa e do camponês. Seguindo Lloyd (2012: 353), ao analisar a obra de Eurípides devemos acrescentar mais dois espaços: um extracênico e outro distanciado. O primeiro deles, extracênico, é representado por vezes por uma porta que divide o interior do exterior, ou seja, o limite entre o que é visível e o que é interdito à audiência. Os assassinatos, por exemplo, ocorrem nesse espaço vetado ao espectador. Em geral, os personagens emergem do interior e relatam o que aconteceu; quando muito, é possível ouvir barulhos vindos de dentro desse recinto: o coro ouve os gritos de Clitemnestra ecoarem do interior da casa no momento do seu assassínio (v. 1166). O segundo espaço, distanciado, não é representado no palco: conhecemo-lo através de um discurso de mensageiro, referência de algum personagem; é o caso da fazenda de Egisto, da fazendola do ancião, ou do túmulo de Agamenão.

Se a Orestes, o maior dos desafetos da realeza de Argos, coube o exílio, à inconformada Electra era necessário neutralizar. Enquanto em Ésquilo e em Sófocles ela é mantida no palácio, em Eurípides ela é dada em casamento a um camponês pobre. $\mathrm{O}$ ardil de Egisto visava enfraquecer a prole da princesa, evitar que ela tivesse um filho de um nobre às escondidas, um dos tantos pretendentes à sua mão. Não bastando o casamento ultrajante, era necessário afastá-la do palácio para terras distantes. Assim, ela deixa a casa paterna e segue para a khóra, onde terá por morada a miserável choupana do seu esposo e uma rotina de trabalhos domésticos de uma camponesa pobre qualquer.

Dirijamo-nos, portanto, à hinterlândia, deixemos as portas das muralhas fortemente vigiadas por filas de lanceiros, devido ao temor de Egisto com um eventual retorno de Orestes. Assistamos ao constante ir e vir entre os espaços do palácio e o mundo rural: (1) O rei ultrapassa os longos muros e se dirige a sua propriedade no campo, onde se preparava para realizar um rito às Ninfas; (2) Clitemnestra deixa o palácio e com um séquito de escravas segue tranquilamente para a khóra, primeiramente para a casa de Electra, mas desejava em seguida ir à propriedade rural real acompanhar o esposo no ritual que ele organizava; (3) O ancião é chamado por Electra - deixa a sua propriedade nos confins da pólis e segue em direção à choupana da princesa, quando avista ao longe Egisto. No caminho, ele desvia para homenagear Agamenão, libando o seu túmulo e nele depositando oferendas. Ao sair da casa de Electra, segue em direção ao palácio para sua última missão - entregar uma mensagem da filha à rainha; (4) As moças que compõem o coro, filhas de cidadãos sem exclusão, moram no campo, onde transitam felizes enquanto ouvem de um caminhante das montanhas o anúncio de que se aproximava o festival de Hera; (5) Electra sai de casa para ir buscar água em uma fonte próxima; (6) Seu esposo deixa o casebre muito cedo e segue para o campo, labuta durante todo o dia e retorna à tardezinha; na sequência, a pedido da esposa, segue para os confins de Argos em busca do ancião e de mantimentos para seus hóspedes; (7) Finalmente, o retorno de Orestes com sua pequena comitiva, Pílade e algum servo, é projetado nesse espaço além-muros. É de uma eskhatiá que ele nos fala: "Chego aos limites desta terra, de onde partirei a pé para outra se algum dos vigias me reconhecer" (v. 95-97) É noite quando ele visita o túmulo do pai, depois segue pela estrada até uma fonte onde se encontra com Electra, e juntos vão para a casa dela. Na sequência, o príncipe se dirige à propriedade de Egisto, onde o mata e retorna para casa da irmã. (8) Não menos importante, é também na khóra que está localizado o sepulcro de Agamenão, enquanto em Ésquilo e em Sófocles ele estava próximo ao palácio.

Não só o vai e vem de pessoas pode ser constatado entre esses espaços, mas a circulação de notícias é constante. O que ocorre no interior dos muros em certa medida é de conhecimento de pessoas que habitam em rincões distantes e

5 Todas as citações da Electra de Eurípides foram retiradas da tradução de Sacconi (2012). Quando desejamos buscar os termos na língua grega, lançamos mão de Diggle (1981). 
vice-versa. Apenas o coro de moças argivas em determinado momento demonstra desconhecer o que se passa em função de habitar o campo: "Estando longe da urbe [ásty], não conheço os males da cidade [pólis], mas agora desejo aprender" (v. 298-299). À medida que se distancia da ásty, o modo de viver e o modo de pensar vão se diferenciando em alguma medida. A distância do centro urbano e do seu cotidiano propiciam novos laços de integração entre as comunidades interioranas e entre povos que habitam as divisas da cidade. É sintomático o registro de Michel Gras (1998: 144) recordando a passagem de Aristóteles (1960), quando o filósofo menciona as diferentes visões que os habitantes do território têm sobre a fronteira, motivo pelo qual havia em algumas cidades a proibição àqueles habitantes das proximidades das fronteiras de deliberarem sobre conflitos com povos vizinhos, pois que o seu particular interesse não lhes possibilitaria um julgamento imparcial.

É buscando água na fonte que Electra é surpreendida pelo seu irmão. $O$ príncipe então enceta um relato enganoso, fazendo-se passar por um mensageiro que traz notícias de Orestes. Sem de nada desconfiar, ela se dirige com o irmão e sua pequena comitiva para frente da sua casa. Quando seu esposo retorna da lide no campo e Electra diz que está diante do mensageiro, portador de notícias do príncipe, prontamente o camponês abre a porta da sua casa e se mostra o melhor dos anfitriões. Contudo, em que pese a atitude nobre do pobre camponês, a casa é desguarnecida de víveres e não está pronta para oferecer o banquete aos hóspedes.

A princesa, preocupada com o tratamento que o marido dispensa aos recém-chegados, considerando um erro acolhê-los em casa tão pobre, decide buscar auxílio material junto ao velho preceptor do seu pai. Solicita rapidamente ao marido: "Chama-o, já que eles chegaram, para vir e oferecer um jantar de boas-vindas" (v. 410-415). A situação do camponês é muito difícil, ele é um autorgós, como Eurípides o chama, ou seja, trabalha sozinho no campo sem ajuda de escravos ou familiares, portanto é ele quem deve arar a terra e cuidar dos animais. Em que pese sua miserabilidade, ele chama a atenção da esposa e antes de partir pede a ela para entrar e improvisar uma refeição para os hóspedes com o pouco que tem em casa; ele bem sabe que os viveres da sua dispensa só são suficientes para aquele dia.

Antes de conhecermos a fazendola do ancião na eskhatiá em que habita, passemos a alguma teoria sobre essa área de confins.

\section{(Re)definindo a eskhatiá}

Existem duas vertentes de análise a respeito da inserção ou não da eskhatiá no território da cidade. Para alguns estudiosos, trata-se de um espaço além da jurisdição da pólis (Ellinger 1981: 70-71). Para outros, como Denis Rousset (1994), Giovanna Daverio-Rocchi (1988) e Maurizio Giangiulio (2001), essa área faz parte do território da cidade e nela está integrada econômica e politicamente, posicionamento que assumimos no Labeca (2010).

Contudo, ainda é de uma definição clássica de eskhatiá, postulada em 1960 pelo epigrafista Louis Robert, que muitos estudiosos lançam mão. Para Robert (1960: 304-305):

\section{A eskhatiá em uma cidade grega é a} região para além das culturas, dos dominios e das fazendas que ocupam as planicies e os vales; é a região da extremidade, as terras de baixa produtividade e de utilização difícil ou intermitente, nas proximidades da montanha ou na montanha que sempre margeia o território de uma cidade grega; elas se situam ao lado da região fronteiriça ou se fundem a ela, aquela região de montanha e de florestas que separa dois territórios de cidades, deixada para uso dos pastores, dos lenhadores e dos carvoeiros.

A concepção de uma eskhatiá à margem da cidade, ventilada por Louis Robert, possivelmente ancorada no retrato de uma eskhatiá fora do espaço da khóra, como preconizava Adolf Wilhem (Giangiulio 2001: 335), parece tomar fôlego e ser reproduzida por vários estudiosos desde então, como um "abre-te Sésamo" criticado por Rousset (1994: 97; Giangiulio 2001: 335). Pierre Vidal-Naquet (1981: 156), para delinear 
o espaço fronteiriço (eskhatiá) da Beócia com Atenas, o que ele denomina de "bouts du mond", recorre à conceituação de Louis Robert. Em 2011, Nadia Coutsinas, analisando os territórios e fronteiras das cidades cretenses no Período Helenístico, afirma que "a definição mais completa de confins (eskhatiä) foi dada por L. Robert" (Coutsinas 2011: 249).

No quadragésimo Convegno di Studi sulla Magna Grecia realizado na cidade de Tarento, em 2000, Maurizio Giangiulio retoma o tema eskhatiá e, partindo de uma crítica ao conceito formulado por Robert, propõe-se a uma nova análise sobre o espaço da eskhatiá. Em 1993, Denis Rousset, em uma comunicação apresentada no Centre Gustave Glotz, já havia recobrado o tema da eskhatiá sob novas bases. Rousset analisou mais de duzentas inscrições sobre as fronteiras das cidades gregas, examinando toda sorte de informação, particularmente abrangente para as regiões da Argólida e da Tessália; não há registro de inscrição do período Arcaico, para o Clássico somam-se quinze, enquanto para o Helenístico registra-se notável riqueza documental (Rousset 1994). Desse trabalho colossal Giangiulio é devedor.

Em sua comunicação, publicada no ano seguinte ao Convegno, Giangiulio (2001: 335 336) alega que o modelo dicotômico de Louis Robert falha ao opor a planície à montanha, a agricultura ao pastoreio e à extração da madeira e o centro à periferia, reafirmando a antinomia projetada no imaginário social da pólis. Nesse mesmo viés, Richard Buxton (1992) traça um quadro do aparato mental grego sobre a concepção das montanhas - o Taigeto, o Olimpo, o Parnaso, o Helicon, o Ida, entre outras tantas. No universo imaginário, elas estão a uma altitude fora do espaço habitado e cultivado - fora da pólis, da ásty e da komai, são espaços de pastoreio, da extração da lenha, dos carvoeiros, espaço de caça, de viagens de indivíduos e de exércitos. O Helicon, por exemplo, é um caminho, uma rota, é ainda o espaço da educação militar do menino antes de tornar-se um hoplita. Entretanto, Buxton lembra que a moeda da marginalidade tem o seu outro lado e nós não podemos nos esquecer da nostalgia do campônio Diceópolis ao relembrar o campo querido e distante em
Acarnenses de Aristófanes (v. 33-36). Continua Buxton, esse imaginário do espaço selvagem das montanhas estende-se também aos deuses Zeus aparece inúmeras vezes como o deus das montanhas, associado à chuva, enquanto Atena está relacionada à cidade. Outras tantas divindades são associadas às terras de confins, às montanhas - Hélio, Ártemis, Dioniso, Deméter, Pan, Apolo, Hermes. Para Buxton, essa imagem é fruto do estruturalismo ligado a Jean Pierre Vernant, que opera com séries de oposição, cidade versus campo, deuses da cidade versus deuses do campo. Para discutir essa propalada dicotomia entre cidade e campo e como essa distorção atinge também deuses e santuários, Irene Polinskaya (2006) faz um esforço para demonstrar que na paisagem sagrada grega há um contínuo e não uma dicotomia entre divindades do campo e divindades da cidade ou entre os espaços da ásty e os do campo.

Retomando Giangiulio (2001), em sua perspectiva a visão dicotômica é fruto de uma ideologia da cidade que vê o centro urbano como centro civilizacional. Assim, de um lado está a eskhatiá - montanhosa e inóspita - e do outro o centro político (e agrícola). Giangiulio insiste que se observe mais detidamente a documentação, particularmente a epigráfica, posto que o que se observa é uma pluralidade de eskhatiai inserida na paisagem agrária (2001: 347).

Afirma Giangiulio (2001: 355):

Se a "margem" selvagem e inóspita ocupa um papel sobre o plano simbólico e ideológico no imaginário da coletividade e/ou de qualquer ambiente, a realidade da organização territorial da pólis e a sua representação parecem substancialmente prescindir da dicotomia que coloca simplesmente em campo o centro e a periferia, enquanto fornece articulação mais complexa e diferenciada.

A partir da análise de um conjunto de textos, da documentação epigráfica e da arqueológica sobre a eskhatiá, o supracitado autor alerta que é preciso tomar cuidado ao propor um modelo de território que 
traduza em termos realísticos sobre o plano topográfico e socioeconômico a alteridade das áreas marginais, reproduzindo o imaginário social da pólis. Por óbvio, se tomarmos o Filoctetes, de Sófocles, isoladamente, teremos por força de seguir o modelo dicotômico da eskhatiá, típico de contextos míticos e rituais, quando a inversão é o ingrediente principal. O aspecto selvagem da eskhatiá só faz sentido no aparato mental, quando o efebo deixa a ásty temporariamente e experiencia um rito de passagem que ao final o introduzirá na comunidade cívica, investindo-o da cidadania.

Segue Giangiulio a observar propriedades localizadas na eskhatiá homérica: a propriedade de Eumeu ou a de Laertes onde é possível observar um nível de abastança que não faz jus a uma eskhatiá selvagem e inóspita.

Em acréscimo, relembra a passagem da Odisseia (XVIII: v. 355-365) em que Eurímaco, homem da horda palacial, um astós, desdenha do mendigo, Odisseu disfarçado. O nobre diz para o mendigo que poderia oferecer-lhe um trabalho em sua fazendola em uma eskhatiá, provendo o seu sustento. Contudo, segundo Eurímaco, não era esse o objetivo do maltrapilho que desejava tão somente viver perambulando e pedindo como um malandro. Giangiulio considera que a partir da escala de valor da épica homérica, o preconceito deita-se não no espaço onde está localizada a propriedade agrícola, mas na condição subordinada do trabalho.

Em conclusão, Giangiulio chama a atenção para a diversidade tipológica da situação de fronteira e postula:

Se muitas eskhatiai podiam ser abandonadas ou mal cultivadas, resta o dado essencial: vale a dizer que o complexo da documentação recomenda pensar uma pluralidade de eskhatiai inserida na paisagem agrária, coinvolta no contexto da atividade econômica do mundo da cidade e não periférica em relação ao território da pólis em seu complexo. (Giangiulio 2001: 355)

De porte do aparato teórico, visitemos a partir de agora o nosso protagonista e conheçamos algum detalhe da sua propriedade rural.

\section{Da propriedade do ancião: a economia rural na eskhatiá da Electra}

Após o assassinato do rei Atrida, Egisto tratou rapidamente de eliminar seus adversários ou afastá-los das redondezas do palácio. Ao fiel preceptor de Agamenão coube a expulsão da pólis (v. 412). Levando em consideração que a pólis engloba tanto a ásty, quanto a khóra e a eskhatiá, entendemos que o velho foi banido da totalidade dos espaços da cidade, diferentemente de Electra, expulsa da ásty. Logo, a princípio ele deveria abandonar toda e qualquer circunscrição de Argos. Entretanto, não é o que acontece. A jovem indica-nos o seu endereço: "Está próximo ao rio Tânao que separa os limites [óros] de Argos das terras espartanas e acompanha os rebanhos tendo sido expulso da cidade [pólis]" (v. 410-412). Certamente, não desejoso de abandonar a pátria, que em alguma medida era a sua, assentou-se na extrema fronteira de Argos, permanecendo em seus arrabaldes, onde mantém uma propriedade privada ${ }^{6}$, distante do alcance imediato de Egisto. Anna Muggia (1997: 19) nos informa que a ocupação ilegal das terras de confins deveria ser um fenômeno bastante frequente. $\mathrm{O}$ registro mais contundente é do século IV a.C. e vem da Tavole di Eraclea, em que as duas inscrições registram procedimentos legais da pólis para recuperar terras sagradas usurpadas por indivíduos.

André Bernand declara que toda a peça se passa nos confins da Argólida e da Lacônia, nas montanhas que dominam a região da Tireatide, terras que suscitam conflitos entre Esparta e Argos e que no momento da representação da peça está sob a possessão de Esparta (Bernand 1985: 246). Jim Roy (1996: 105) considera os versos 95-97, quando Orestes revela que não seguirá para ásty e fugirá a pé para outra cidade se for descoberto por um vigia de Egisto, para afirmar que a casa do camponês está próxima à fronteira argiva. Em seu auxílio, Roy cita

6 Há uma discussão em torno da existência ou não de propriedade privada na extrema fronteira. Nas inscrições estudadas por Rousset, a exploração agrícola nas terras de confins é rara e a propriedade privada quase não aparece; quando aparece não aponta para a existência ou não de construções (Rousset 1994: 122-123). 
Cropp (1988: 98), que acredita que a casa de Electra fica próxima aos limites de Argos, na parte superior do Vale do Ínaco, entre Mantineia e Argos. Em que pese a afirmação de Roy, ele declara que algumas passagens sugerem posição menos precisa dentro do Vale e, ademais, que o poeta não tem motivos para narrar distância ou tempo de viagem com precisão. Continua Roy, não há como calcular uma distância precisa entre a propriedade do velho e a do camponês, embora Cropp (1988) projete algo em torno de trinta e cinco quilômetros de distância (Roy 1996: 107; Cropp 1988).

Façamos algumas considerações: primeiro, as distâncias não parecem muito grandes entre a propriedade de Egisto e a casa de Electra. Segundo, Orestes não parece estar muito distante de onde ele falou que fugiria a pé para outra cidade se os vigias o flagrassem ali (v. 95-97). Mas na sequência ele caminha pela estrada até a fonte onde encontra a irmã. Não sabemos quanto ele caminha, que distância ele percorre. Portanto, as distâncias não são claras no texto. Não há nada que indique com precisão que a casa de Electra, embora distante da ásty (v. 246), de íngreme acesso (v. 489), em uma montanha escarpada (v. 210), esteja perto da casa do ancião ou em uma eskhatiá. Em conclusão, é possível afirmar com segurança apenas que a propriedade do ancião está em uma eskhatiá - ou seja, em terras limites, que divisam duas cidades - entre Esparta e Argos, próximo ao rio Tânao. É importante frisar que não vemos a palavra eskhatiá7 na obra. Vemos a palavra óros com o nítido sentido de fronteira, limite, divisa: "Ele [o ancião] está próximo ao rio Tânao que separa os limites [óros] de Argos das terras espartanas." (v. 410-411) Outro termo que designa fronteira/limite na Electra euripidiana é térmon: "Chego aos limites [térmonas] desta terra" (v. 96).

É notoriamente estranho que o ancião, uma vez banido, permaneça na cidade, $\mathrm{e}$ igualmente perturbadora é a facilidade com

7 Das trinta e duas tragédias que nos chegaram na íntegra, a única em que aparece a palavra eskhatiá é no Filoctetes de Sófocles (v. 144), designando o espaço nos extremos onde jaz o herói, Filoctetes. que se movimenta na khóra, inclusive com acesso ao palácio. Sua mobilidade, para além da disposição de Eurípides em torná-lo um personagem central, com tantas atribuições, pode residir no fato de que, a princípio, sua origem servil não representava grande perigo ao trono aos olhos de Egisto. O tirano estava preocupado com o provável retorno de Orestes e de aliados nobres. O banimento do ancião pode ter se dado muito mais no sentido de apagar da memória do povo a imagem de Agamenão, afastando aquele que propagava aos quatro ventos a excelsa glória do Atrida.

Se para Egisto o ancião poderia não representar grande perigo era porque ele não contava com a teia que o poeta tecia para apanhá-lo. Bem ao gosto de Eurípides introduzir personagens de baixa extração social em suas peças com significativos papéis (Romilly 1986: 5) ${ }^{8}$, o ancião é o homem imprescindivel no desenrolar da trama. Dois aspectos importantes devem ser destacados: esse papel ímpar que ele ocupa e o aspecto econômico/ produtivo da sua propriedade na eskhatiá.

Observemos o papel de primeiro escalão ocupado por nosso personagem. Inicialmente o ancião é um agente importante do ponto de vista econômico. Ele responde sem demora à solicitação de Electra e fornece suprimentos para o banquete aos hóspedes e para mantê-los na casa da princesa enquanto traçam os planos e executam os crimes. Em segundo lugar, o ancião é a peça chave de um dos momentos áureos do drama - o reconhecimento (anagnórisis). Lembremos, aliás, que Orestes é salvo pelo ancião que o envia ao exílio depois do assassinato de Agamenão. Em terceiro lugar, o ancião desempenha um papel vital nos homicídios do tirano e da rainha?.

8 Vale mencionar também o papel de destaque que coube ao camponês, o nobre esposo que honra a linhagem Atrida e mantém a princesa virgem, auxilia-a em seus planos de vingança e, principalmente, é o primeiro personagem a ser apresentado ao público, o responsável pelo Prólogo.

9 Em artigo publicado na Revista Brasileira de Estudos Clássicos - Electra e Orestes: os efebos euripidianos na khóra de Argos - desenvolvemos a ideia de os príncipes Atridas, encarnados em única uma persona, participarem conjuntamente do ritual da efebia; na analogia, coube ao 
Orestes retorna a Argos com o oráculo que dizia que ele deveria matar Egisto e a sua mãe, mas ele é auxiliado pelo ancião, que endossa o seu desejo de vingança afirmando categoricamente que ele deve cometer os homicídios (v. 613). $\mathrm{O}$ assassinato de Egisto é orquestrado minuciosamente pelo ancião, que mune Orestes de praticamente todos os passos da ação no intuito de "tomar a casa paterna e a cidade" (v. 610-611). A Orestes caberá uma parcela, pois como todo bom mestre, o ancião o prepara para tomar as medidas que fogem ao seu alcance: "Pensa tu mesmo a partir daí." (v. 639) Em relação à morte da rainha, todo plano é traçado por Electra, porém o ancião é seu cúmplice e é ele quem leva a mensagem do falso nascimento do filho de Electra à rainha, atraindo-a ardilosamente à casa da princesa, onde os irmãos cometerão conjuntamente o matricídio.

Passemos ao aspecto econômico/produtivo da propriedade do ancião. Observemos no mapa a região de fronteira, a eskhatiá, nas bordas do rio Tânao. Na expectativa de bem guarnecer os seus hóspedes, Electra solicita ao marido buscar o providencial auxílio material junto ao ancião: "Chama-o, já que eles chegaram, para vir e oferecer um jantar de boas-vindas." (v. 410-415) O velho é a única pessoa a quem ela pode recorrer, pois como afirma, "do palácio paterno, junto à mãe, não obteríamos nada” (v. 417).

$\mathrm{O}$ ancião prontamente atende ao chamado de Electra. Ele deixa a sua propriedade em direção à casa da princesa para levar-lhe pessoalmente os víveres, mesmo sentindo o peso da idade e se arrastando com dificuldades através da planície pedregosa. A despeito de sua notória debilidade física, ainda há disposição para desviar do seu percurso e visitar o túmulo de Agamenão para homenagear o homem de quem ele muito se orgulhava: "Libei, abrindo o odre que trago aos hóspedes, e ao redor do túmulo espalhei ramos de mirto." (v. 511-512)

Cansado, emocionado, tomado de ternura e compaixão, o ancião chega enfim à morada de difícil acesso de Electra: "Ó filha [...], chego e trago a ti, subtraído do meu rebanho de

ancião o papel de condutor dos efebos em seu ritual de passagem (Ribeiro 2016). carneiros, este filhote recém-nascido, estas coroas, os queijos retirados da prensa, e este antigo tesouro de Dioniso, rico em aroma." (v. 493-498)

O ancião, além de cuidar do seu rebanho, produz queijos e possui vinho de boa qualidade em sua fazendola, além de flores (v. 496) e mirto (v. 511). Eurípides nos revela assim a existência de uma propriedade privada localizada em uma área de eskhatiá e com aproveitamento econômico significativo.

A partir de tais informações pensemos no que é possivel prospectar da fazendola do ancião. Para dispor dos bens que oferece a Electra, seria indispensável uma extensão razoável de terra para poder facultar o trabalho em mais de uma frente. Além de campos aráveis, seria necessária uma estrutura, ainda que mínima, para a produção do queijo, outra para a fabricação do vinho e pasto para criação do rebanho. O velho homem demonstra possuir o básico para subsistência, aquilo que é possivel a ele produzir. Nada indica uma pobreza extremada. Pelo contrário, sua situação econômica é bem melhor que a do camponês, esposo de Electra, que só tinha em casa o indispensável para um dia, como já vimos. Contudo, por óbvio, sua fazendola está significativamente distante das condições da propriedade rural de Egisto. A fazenda real é muito mais próspera, com seus campos de pastagem, de onde vinham os animais para o sacrifício, seus jardins irrigados e bem cuidados, a casa mobiliada e o vai e vem de escravos no altar. A propriedade rural da realeza, portanto, estava apta a oferecer soberbo banquete a Orestes, disfarçado de atleta, e sua comitiva, bem como recepcionar a rainha que tinha planos de para lá se dirigir após o ritual na casa da filha.

Conquanto longe de se assemelhar à fazenda do tirano, é digno de registro que o ancião possua de pronto vinho e queijos em seu estoque para atender sem dificuldade a Electra, o que pode significar uma produção constante e excedente ao seu consumo imediato, revelando uma condição econômico/financeira no mínimo estável. Não pode ser outra nossa conclusão a partir do fato de que tanto o fabrico do queijo quanto a produção do vinho demandam um tempo próprio, dado que ao ser solicitado, o ancião já dispunha desses produtos 
em sua reserva. Devemos levar em conta a infraestrutura necessária e os recursos essenciais tanto no que se refere ao laticínio quanto à produção de vinhos: vasilhas apropriadas, prensa para queijos e prensa para uvas, espaços específicos, lenha, locais para armazenagem. $\mathrm{O}$ velho diz textualmente que acabara de tirar o queijo da prensa. Ou seja, da sua propriedade vinha o leite e a ele cabia a produção do queijo. De igual forma, supomos a fabricação do vinho em sua fazendola, o que significa todo o processo que vai desde a plantação da uva passando pela vindima até chegar à produção e embalagem do vinho. Minimamente, o ancião deveria contar com uma podadeira para recolha da uva, cestos para o transporte até o lugar da preparação do suco, talvez até um carro de boi para transporte do parreiral até o local de produção. Seria fundamental ainda um caldeirão ou uma bacia para pisotear o fruto, uma embalagem (ânfora?) para guardar o vinho em temperatura adequada durante o processo de fermentação. Para transportar o tesouro de Dioniso até a casa de Electra sabemos que ele usou um odre (askós, v. 511), recipiente feito de couro animal, geralmente de cabra, comum para essa finalidade. Como o velho morando sozinho em terras tão longínquas poderia fazer todo trabalho? Sabemos que na ausência de escravaria, era comum contar com a ajuda de parentes, de amigos e de jornaleiros livres na época da colheita (Chevitarese 1998). Poderíamos supor imaginariamente que o velho contava com mais algum servo expurgado junto com ele para as terras de confins ou com algum caminhante da montanha, um pastor interessado em uma meação. Lembremos que ele não deve ser um autorgós, aquele que trabalha sozinho a sua terra; essa alcunha cabe ao camponês nas palavras de Eurípides, conforme mencionado.

Há de se considerar, portanto, que o ancião dispunha de uma propriedade com nível considerável de aproveitamento econômico. Em relação as suas vestes, vemo-lo com o peplos em farrapos (v. 501), mas, como um velho homem confinado à lide no campo, não poderíamos imaginar que os trajes fossem diferentes. Todavia, há indicativos de que também houvesse meios de confeccionar mesmo que rudimentarmente as próprias roupas, tal qual acontece na casa de Electra, onde ela mesma precisava tecer as suas vestes ou andaria nua (v. 307-308).

Reiteradamente vemos alusão a um possível diálogo entre a cena do ancião de Eurípides e a cena da Odisseia (canto XIV), quando Homero leva Odisseu até seu fiel servo, Eumeu (Sacconi 2012; Cropp 1988). É significativo que Eumeu, vendo a situação lamentável do palácio, tomado pelos pretendentes de Penélope, constrói um recinto para a criação de porcos do amo sem o conhecimento da rainha e de Laertes. Como ele afirma, se o amo tivesse envelhecido ali, faria o que um rei benevolente costuma fazer com um estimado servo - ofertar-lhe uma casa, um terreno e uma boa mulher. Ele próprio construiu com grandes pedras o seu espaço amplo e belo - com suas doze pocilgas e trezentos e sessenta porcos, com os quais ele abastecia o palácio; ali estava o seu casebre simples. Será nesse espaço - um rincão belo, arborizado, por cima das serras, afastado de tudo, que Odisseu vai procurar pelo velho. Eumeu recebeu com fina hospitalidade o velho viandante (Odisseu disfarçado), preparou-lhe no espeto a carne de porco e ofereceu-lhe o doce vinho. Na sequência desabafou com o estrangeiro as desventuras da casa do seu amo e relatou como os pretendentes devoravam os bens e dilaceravam o patrimônio que nenhum herói possuía semelhante ao seu (Odisseia, XIV: 5-70). Depreendemos do texto grego que tal propriedade se localizava na eskhatiá de Ítaca. Quando Eumeu enumera os bens de Odisseu, vemos, no verso 104 do canto XIV, a palavra eskhatiá fazendo referência ao lugar onde as cabras pastam, ao que tudo indica muito próximo de onde está Eumeu. Embora a ampla e rentável propriedade pertença ao oikos de Odisseu, a posse pertence ao servo, diferente da propriedade privada do ancião. Certamente tanto Agamenão quanto Odisseu teriam presenteado aos seus devotados servos com propriedades. Feita a comparação entre o velho da epopeia homérica e o da tragédia, retornemos ao último. Importante ressaltar é que em ambos os casos, as fazendolas possuem bom aproveitamento econômico. 
Das margens ao centro da ação, o ancião trágico, tanto no que se refere a sua origem servil quanto ao banimento para os confins da cidade, portava todos os requisitos para ser um personagem menor; contudo ele cresce em magnitude nas mãos de Eurípides. Necessariamente temos de pensar que o espaço exerce forte influência sobre ele. Habitar as terras de confins de Argos dá a esse homem a liberdade que o ambiente palacial dominado por Egisto lhe restringiria. Vulto de maior mobilidade física dentro da tragédia, ele conhece os espaços e os hábitos de todos; por esse motivo é o conselheiro ideal para Orestes, alçado a este posto pelo jovem príncipe que nele deposita plena confiança (v. 618). O ancião é o segundo nome na hierarquia da casa real que o "futuro" rei Orestes pretende restabelecer. O extraordinário informante/ consultor conhece os vícios e as virtudes dos nobres (v. 550-551) e o comportamento vacilante dos escravos (v. 632-633), sabe de alguma forma o que se passa no espaço intramuros da cidade argiva, informa a Orestes sobre o rígido esquema de segurança das muralhas, precavendo-o para se manter afastado delas; viu Egisto a caminho de sua propriedade, sabe que o rei leva tão somente escravos consigo; é ele quem visita o túmulo. Ele sabe que Clitemnestra não acompanhou o esposo à propriedade rural porque temia a censura do povo, porém se juntaria a ele em seguida. Por outro lado, considerando a condição anterior do ancião, de preceptor de Agamenão, Eurípides, ao colocá-lo novamente em posição de destaque, restaura a importância do personagem na concepção, desenvolvimento e desfecho da tragédia, restituindo-lhe em certa medida a condição de preceptor, desta feita em relação a Orestes. Sobretudo, é a partir da atuação desse ator de primeira grandeza que temos a possibilidade de adentrar nas áreas marginais da pólis.

\section{Considerações finais}

A khóra de Eurípides mostra-se complexa, pulsante, com túmulo, casas, propriedades, santuário, estábulos, estradas, rios, pessoas em constante movimentação, e nos dá a entrever múltiplas facetas: (1) aspectos políticos como na opção da casa real em manter uma propriedade no campo, interligando esse espaço à ásty e consequentemente assegurando o poder sobre o território; (2) aspectos religiosos - uma khóra como centro da maior homenagem a principal divindade de Argos, o Festival de Hera; espaço privilegiado para rituais, a exemplo do ritual às Ninfas que o rei organiza não no espaço urbano, mas em sua fazenda no campo, e do ritual pelo nascimento do suposto filho de Electra; (3) aspectos econômicos - propriedades rurais bastante diferentes: um camponês (autorgós), que lida sozinho na própria terra e tem por ajudante apenas a esposa que cuida das tarefas domésticas, uma fazenda suntuosa de propriedade da família real e uma fazendola nos confins de Argos, assentada em uma eskhatiá, que nos deixa entrever algum aproveitamento econômico.

$\mathrm{Na}$ reescritura da tragédia sob a batuta de Eurípides, no jogo entre o herói mítico de um lado e o homem e seu cotidiano do século $\mathrm{V}$ a.C. de outro, como bem nota Vernant na epígrafe que abre esse texto, o poeta nos apresenta a pólis do seu tempo. Em sua cidade ásty, khóra e eskhatiá formam um contínuo que não nos dá margem para pensar em qualquer possibilidade de uma dicotomia entre os espaços rural e urbano, muito menos imaginar que a muralha demarque uma fronteira ou ainda que impeça o vai e vem entre esses espaços. Os limites da pólis na Electra, suas eskhatiai, podem ser observados em sua particularidade, abrindo a possibilidade para se encontrar nesse espaço além de lenhadores, pastores e carvoeiros a existência de propriedade privada e algum aproveitamento econômico. Portanto, o retrato pintado por Eurípides, à luz dos novos estudos sobre a khóra e as terras que margeiam a cidade, faz justiça a um quadro verossímil da organização espacial da pólis, com especial enfoque para a topografia da eskhatiá, ainda que se leve em consideração um leve toque poético do tragediógrafo. 
A khóra e alhures: uma observação sobre a eskhatiá na Electra de Eurípides

R. Museu Arq. Etn., 31: 96-109, 2018.

RIBEIRO, M.C.L. A khóra e alhures: uma observação sobre a eskhatiá na Electra de Eurípides. R. Museu Arq. Etn., 31: 96-109, 2018

Abstract: Euripides ( 485 b.C.- 406 b.C.) took to the stages of the theatre of Athens a sui generis interpretation of the myth of Electra around 415 b.C. The poet cleverly transferred the narrative to a rural environment and added a major character in the progression of the play, the preceptor of Agamemnon. Expelled from the asty by the tyrant Aegisthus, the old preceptor lives in the border of the city and performs agrarian activities in his property. Our goal is to analyze the small farm of the loyal servant of the Atrida family, located in the eskhatiá. Some modern studies understand these surrounding lands as unproductive or exclusively destined exclusively to minor activities such as hunting and wood extraction, as isolated from the polis; unlike these, we corroborate studies that consider the eskhatiá as an integrated space of the polis, a complex, plural, and often productive space.

Keywords: Euripidean tragedy; Electra; Khóra; Eskhatiá

\section{Referências bibliográficas}

Aristophanes. 1992. The acharnians, the knights, the clouds, the wasps. Tradução Benjamin Bickley Rogers. Harvard University, Cambridge.

Aristote. 1960. Politique. Tradução Jean Aubonnet. Les Belles Lettres, Paris.

Bernand, A. 1985. La carte du tragique: la géographie dans la tragédie grecque. Centre National de la Recherche Scientifique, Paris.

Bignotto, N. 1998. O tirano e a cidade. Discurso, São Paulo.

Buxton, R. 1992. Imaginary Greek mountains. The Journal of Hellenic Studies 112: 1-15.

Chevitarese, A.L. 1998. Parentes, amigos e assalariados livres na agricultura Ática no período clássico. Phoînix 4: 47-58.

Coutsinas, N. 2011. Territoire et frontières des cités crétoises hellénistiques: l'exemple de Lato. In: Kourtessi-Philippakis, G.; Treuil, R. (Orgs.). Archéologie du territoire, de l'Égée au Sahara. Université Paris 1 Panthéon-Sorbonne, Paris, Cahiers Archéologiques de Paris 1, n. 2, 245-255.
Cropp, M. J. 1988. Euripides: Electra. Warminster, Wiltshire.

Daverio-Rocchi, G. 1988. Frontiera e confini nella Grecia Antica. L'Erma di Bretschneider, Roma.

Diggle, J. 1981. Euripidis Fabulae. Oxford University, Oxford, v. II.

Ellinger, P. 1981. Ártemis. In: Bonnefoy, Y. (Org.). Dictionnaire des mythologies. Flamarion, Paris, 70-71.

Ésquilo. 2008. Oresteia: Agamenon, Coéforas, Eumênides. Tradução Manuel de Oliveira Pulquério. Setenta, Lisboa.

Florenzano, B.B. 2014. Defining the Greek polis: the role of borders in the articulation of space. Labeca/ MAE-USP, São Paulo.

Giangiulio, M. 2001. L'eschatia prospective critiche su reppresentazione Antiche e Modelli moderni. In: Atti del 40 Convegno Magna Grécia. Istituto per la Storia e l'Archeologia della Magna Grecia, Taranto, 2001, 333-361. 
Gras, M. 1998. O Mediterrâneo arcaico. Tradução Telma Costa. Teorema, Lisboa.

Homero. 2010. Odisseia. Tradução Frederico Lourenço. Cotovia, Lisboa.

Kormikiari, M.C.N. et al. 2011. O estudo das fronteiras no mundo antigo: o caso grego. In: Aldrovandi, C.E.V.; Kormikiari, M.C.N.; Hirata, E.F.V. Estudos sobre o espaço na Antiguidade. Edusp, São Paulo, 125-156.

Laboratório de Estudos sobre a Cidade Antiga Labeca. 2009. Cidade e território na Grécia antiga: organização do espaço e sociedade (projeto de pesquisa). Labeca. Disponível em: <https://goo.gl/W8YH2Q>. Acesso em: 1/6/2009.

Laboratório de Estudos sobre a Cidade Antiga Labeca. 2010. A organização da khóra: a cidade grega diante da sua hinterlândia (projeto de pesquisa). Labeca. Disponível em: <https://goo.gl/ qgLz3H>. Acesso em: 9/2/2018.

Laboratório de Estudos sobre a Cidade Antiga Labeca. 2013. Glossário. Labeca. Disponível em: $<$ https://goo.gl/QgwjSz>. Acesso em: 14/2/2018.

Lewis, D.M. 2008. Mainland Greece, 479-451 B.C. In: Lewis, D.M. et al. The fith centuty B.C. Cambrigde University, Cambridge, Cambridge Ancient History, v. 5, 96-120.

Lloyd, M. 2012. Space in Euripides. In: Jong, I.J.F. (Ed.). Space in ancient Greek literature. Brill, Leiden, Studies in Ancient Greek Narratives, 341-357.

Muggia, A. 1997. Le premesse della ricerca. In: Muggia, A. L' area di rispetto nelle colonie magnogreche e siceliote. Sellerio, Palermo, 13-55.

Polinskaya, I. 2006. Lack of boundaries, absence of oppositions: the city-countryside continuum of a Greek Pantheon. In: Rosen, R.M.; Sluiter, I. City, countryside, and the spatial organization of value in classical antiquity. Brill, Leiden, 61-92.

Ribeiro, M.C.L. 2015. Representações da cidade na tragédia grega: entre o espaço construído e o espaço concebido. Tese de doutorado. São Paulo: FFLCH/ USP.

Ribeiro, M.C.L. 2016. Electra e Orestes: os efebos euripidianos na khóra de Argos. Classica 29(1): 7-27.

Robert, L. 1960. Recherches épigraphiques. Revue des Études Anciennes 62(3-4): 276-361.

Romilly, J. 1986. La modernité d'Euripide. Université de France, Paris.

Rousset, D. 1994. Les frontières des cités grecques. Premières réflexions à partir du recueil des documents épigraphiques. Cahiers $d u$ Centre Gustave Glotz 5: 97-126.

Roy, J. 1996. The countryside in classical Greek drama, and isolated farms in Dramatic Landscape. In: Shipley, G.; Salmon, J. Human landscapes in classical antiquity. Routledge, London, Leicester-Nottingham studies in ancient society, v. 6, 98-118.

Sacconi, K.A. 2012. Electra de Eurípides: estudo e tradução. Dissertação de mestrado. São Paulo: USP.

Tacla, A.B. et al. 2011. A natureza da cidade portuária e a relação portos-portas em contextos helênicos. In: Aldrovandi, C.E.V.; Kormikiari, M.C.N.; Hirata, E.F.V. Estudos sobre o espaço na Antiguidade. Edusp, São Paulo, 157-195.

Sófocles. 2008. Filoctetes. Tradução, introdução e notas Fernando Brandão dos Santos. Odysseus, São Paulo.

Sófocles. 2009. Electra(s): Sófocles/Eurípides. Tradução Trajano Vieira. Ateliê, São Paulo.

Vernant, J. 2014. Tensões e ambiguidades na tragédia grega. In: Vernant, J; Vidal-Naquet, P. Mito e tragédia na Grécia antiga. Tradução Anna Lia A. de Almeida. Perspectiva, São Paulo, 7-24.

Vidal-Naquet, P. 1981. Le chasseur noir: formes de pensée et formes de société dans le monde grec. Maspero, Paris. 